Work, employment and society

\title{
Is employment polarisation inevitable? Occupational change in Ireland and Switzerland, I970-20 I0
}

\author{
Emily C Murphy \\ University of Oxford, UK

\section{Daniel Oesch} \\ University of Lausanne, Switzerland
}

\begin{abstract}
The routinisation thesis expects technology to hollow out the middle of the employment structure, leading to a uniform pattern of polarisation across affluent countries. This article argues that occupational change is also shaped by labour supply - particularly education and immigration - and institutions. Polarisation therefore represents just one scenario of occupational change. Our study of Ireland and Switzerland examines long-term change in the employment structure (1970-2010), using census data and an encompassing definition of the labour force. Results show no simple trend of occupational upgrading morphing into polarisation. Occupational upgrading occurred in both countries, with the largest employment gains in high-paid occupations and the largest losses in low-paid ones. Patterns of occupational change largely aligned with the evolution of labour supply, upgrading in the 1990s and 2000s being driven in both countries by higher educated women. Immigration supplied labour for low-end and mid-level jobs in Ireland during the Celtic Tiger era, and for low-paid occupations in Switzerland during the 1980s.
\end{abstract}

\section{Keywords}

Census data, employment polarisation, immigration, Ireland, labour supply, occupational structure, Switzerland

\section{Corresponding author:}

Daniel Oesch, Life Course and Inequality Research Centre (LINES), LIVES - Swiss National Centre of Competence in Research, University of Lausanne, $\mathrm{CH}-1015$ Lausanne, Switzerland.

Email: daniel.oesch@unil.ch 


\section{Introduction}

In the early 2000s, a set of studies created a stir in the social sciences by arguing that technological change leads to polarised employment structures (Autor et al., 2003; Goos and Manning, 2007; Wright and Dwyer, 2003). Instead of technology being skill-biased and leading to occupational upgrading, the routinisation thesis views information communication technologies (ICT) as task-biased. Routine jobs concentrated in the middle of employment structures are automated, whereas non-routine jobs at the top and bottom end are complemented by technology (Autor et al., 2003).

Such technological determinism implies that a common polarising trend should first appear in the 1990s across affluent countries, coinciding with the mass diffusion of information technologies (Autor et al., 2008). The theoretical argument has been embraced in economics, although the evidence on job polarisation is far from conclusive. Clear-cut trends have only been shown for the United States (Dwyer, 2013; Wright and Dwyer, 2003) and the United Kingdom (Goos and Manning, 2007). Contrary to the hypothesis of uniform job polarisation, findings for Europe show substantial cross-country variation, with a predominance towards occupational upgrading (Eurofound, 2015; FernándezMacías, 2012; Oesch, 2013; Oesch and Rodríguez Menes, 2011).

Job polarisation may simply be an outcome specific to the nexus between institutions and labour supply found in these two Anglo-Saxon countries. American and British labour markets not only share similar levels of technology, they also share similar liberal wage-setting institutions and migratory regimes. Polarisation could be an outcome specific to an institutional context of liberal wage-setting and large migratory flows, which augments the top and bottom of the labour market (Kalleberg, 2012; McCollum and Findlay, 2015).

Why might occupational trends between countries and time periods differ? The narrative introduced here is that educational expansion, female labour force participation and immigration determine the pool of workers available to employers. Labour market institutions - wage-setting and the welfare state - then influence the price of available workers. Labour demand and labour supply are channelled into specific employment outcomes through national institutions, which thus decisively shape patterns of occupational change. The adoption of technology and the creation of jobs may be, to some extent, endogenous to the evolution of labour supply (Lewis, 2006) and institutions (Acemoglu, 2003; Nolan and Slater, 2010).

This argument is examined by analysing occupational change in Ireland and Switzerland between the 1970s and 2000s. These two case studies are used to assess the polarisation thesis over time. In Switzerland, surges in lower-end immigration in the 1980s were halted as new policies favoured top-end immigration in the 2000s. In Ireland, the boom years following the mid-1990s were accompanied by a dramatic rise in net migration and educational expansion. The evolution of wage bargaining in both countries differs from the US and UK, where Switzerland's coordinated market economy leads to a more compressed earnings structure than Ireland's more liberal wage-setting institutions.

Our article contributes to the debate on employment polarisation in two ways. First, studying the long term (1970-2010) allows us to test whether an onset of employment 
polarisation fits with the predicted timing of a mass diffusion of information technology. For the routinisation thesis to hold, a common polarising trend should be observed - a trend which echoes the American and British trajectory and first appears in the 1990s to coincide with the mass diffusion of ICT (Autor et al., 2008). Second, our article uses large-scale census data and an encompassing definition of the labour force, without excluding civil servants and agricultural, migrant, female or part-time labour.

The next sections provide a conceptual frame for how changes in labour supply and institutions help shape occupational change, and outline the specificities of the Irish and Swiss labour markets. Data and analytical strategy are presented next. Evidence is first shown on long-term occupational change across decades. It is then disaggregated by migrant status, gender and education. The conclusion discusses the implications of our findings for the debate on employment polarisation.

\section{Determinants of occupational change}

\section{Technology and tasks}

The prevailing consensus is that technology drives long-term occupational change (Manning, 2004). Workers are displaced from occupations strongly impacted by technological progress, such as agricultural and manufacturing jobs, and migrate to occupations for which technology has less direct influence, such as jobs in health care and education. David Autor et al. (2003) propose a novel theory of how ICT affects employment change by distinguishing between routine and non-routine tasks. While computers replace routine production and clerical tasks, frequently carried out in mid-wage jobs, they have little impact on either the non-routine cognitive tasks carried out in high-end jobs, or the non-routine personal services carried out in low-end jobs (Autor et al., 2003; Goos and Manning, 2007). Technology is thereby seen as complementary to both highskilled analytical and low-skilled interpersonal service jobs, but a substitute for production workers and clerks in mid-wage jobs. As a result, technology hollows out the employment structure.

The routinisation thesis argues that the skill-biased technical change of the 1980s has given way to polarised change since the 1990s. This prediction is easily tested. Western countries are exposed to the same technological change and should thus have experienced a shift from occupational upgrading in the 1970s and 1980s to employment polarisation in the 1990s and 2000s (Autor et al., 2008: 301).

Evidence supporting the idea that polarisation is a common cross-country phenomenon is, however, far from conclusive. Wright and Dwyer (2003) document a shift in the American job structure from clear-cut upgrading in the 1960 s and 1970 s to even job growth in the 1980s and polarisation in the 1990s. A careful replication study arrived at the same conclusion for the UK (Goos and Manning, 2007).

Other studies of occupational change from the 1980s on point to misfits in categorising the employment structure in the UK as an 'hourglass' (Anderson, 2009; Holmes and Mayhew, 2012). Employment change across European countries shows great variation - where an overall trend can be established it leans towards occupational upgrading rather than polarisation (Eurofound, 2015; Fernández-Macías, 2012; Oesch, 2013). 


\section{Labour supply}

Technology certainly affects firms' demand for labour. Yet firms do not adopt new technologies independently from the kind of workers they find in the labour market. Employers resort to different production techniques and create different types of jobs depending on whether more or less educated workers are in plentiful supply (DiPrete and McManus, 1996: 42). In other words, focusing solely on labour demand is not enough: labour supply is also paramount for occupational change.

The presence of a large pool of unqualified labour seems a precondition for employment polarisation. Growth in low-end jobs will be hampered by a limited supply of workers willing to take on low-paid jobs, be it either less educated nationals or less qualified or more willing migrant workers (McCollum and Findlay, 2015). Where constant educational expansion and a restrictive immigration policy limit the pool of low-end job candidates, employers face stronger incentives to make their production techniques complementary to higher quality jobs.

Is there evidence that shifts in labour supply have affected occupational change? In Ireland, large increases in women's tertiary education in the 1990s resulted in an increasing over-representation of women in top-end public sector occupations (Turner and McMahon, 2011). Irish women's acquisition of degrees in law and medicine was mirrored by a spike in female legal and medical professionals (Keane et al., 2016).

Immigration has been paramount to the expansion of low-end service jobs - and thus for employment polarisation. During the 1990s, two-thirds of jobs created at the bottom end of the American labour market were filled by immigrants (Wright and Dwyer, 2003: 309). Plant-level evidence has shown that immigration surges and a higher share of highschool dropouts in any given metropolitan area meant that manufacturing plants resorted to production techniques with markedly less automation (Lewis, 2006: 35). Governmentcoordinated labour migration in the US over the second half of the 20th century led to unprecedented levels of low-skilled immigration from Mexico, initially to supply farm jobs. Employers encouraged this policy with the goal of maintaining low wage floors (Rodriguez, 2004: 456).

\section{Labour market institutions}

This brings us to a third key factor, which varies across countries and affects the pricing of different supply pools: the institutional context for job creation. Institutions likely channel firms' demand for labour into different occupational outcomes. The idea is that governments have some leeway in how they accommodate technical change and translate it into the organisation of labour (Fernández-Macías and Hurley, 2017; Kalleberg, 2012).

Firms will create fewer low-end jobs in countries where they are given less latitude to set low wages. Legal minimum wages and collective bargaining can foster pay norms that push employers to organise the labour process to produce higher quality jobs (Grimshaw et al., 2013). Where unions and the welfare state lead to wage compression and constrain firms to pay higher wages to less educated workers, firms are pressured to apply new technologies to increase the productivity of less educated workers (Acemoglu, 2003: 127). 
Institutional constraints such as extensive collective bargaining, high minimum wages and generous unemployment benefits encourage employers to opt for a 'high road' job strategy (Streeck, 1997). There is ample cross-national evidence on how institutions affect production techniques and the occupations associated with them in sectors such as retail, food processing and hospital care (Gautié and Schmitt, 2010; Grimshaw et al., 2013).

Cross-country differences in job design are particularly stark in the health care sector, where the employment of low-skilled and poorly paid cleaners and nursing assistants in the US contrasts with the more skilled and better paid jobs of hospital attendants in Denmark. Crucially, hospital technologies are similar across developed countries. It is human resources and organisational strategies that differ substantially, dependent as they are on institutional context (Méhaut et al., 2010: 360).

\section{Institutional dynamics in Ireland and Switzerland}

Two countries, Ireland and Switzerland, are used to analyse the pattern of occupational change. While technological advances in these countries are of comparable levels to other advanced economies, the Irish and Swiss labour markets exhibit critical variation over the last decades with regard to factors that may affect the potential for polarisation: the evolution of labour supply and labour market institutions. Moreover, these two small countries provide us with compact labour markets. This means that while rural/urban employment divisions may arise, the dominance of cities such as Dublin or Cork in Ireland or the Zurich-Basel-Geneva triangle in Switzerland ensures relative homogeneity in policy terms and institutional effects; both countries are less prone to major regional variation in labour markets compared with the US or the UK.

Unlike the slowdown observed in the US (Goldin and Katz, 2007: 152), rising educational attainment has not faltered in Ireland and Switzerland. Both countries experienced a massive surge in educational attainment over the last few decades. This process occurred gradually in Switzerland (Becker and Zangger, 2013). By contrast, Ireland experienced a dramatic expansion in educational participation beginning in the $1980 \mathrm{~s}$ (Barrett et al., 2002; McGuinness et al., 2009). The catch-up effect in educational attainment in the two countries was particularly marked for women.

No other OECD (Organisation for Economic Co-operation and Development) country besides Luxemburg provides as much fluctuation in net migration between 1970 and 2010 as do Ireland and Switzerland - with periods in both countries of high out-migration and high immigration (OECD, 2017). Figure 1 shows the variation in migration over time in the two countries. Coupled with greater numbers of tertiary educated Irish women joining the labour market, immigration and return migration of the high-skilled and tertiary educated in Ireland contributed to an increasingly skilled labour force from the 1990s (Barrett et al., 2002). Ireland's small net immigration in the 1970s plummeted in the 1980s when unemployment peaked at 16 per cent and the higher educated emigrated (Honohan and Walsh, 2002). The Irish economy's spectacular take-off in 1996 attracted large numbers of immigrants into the 2000s.

In Switzerland, the boom of the 1980s brought large numbers of low-skilled immigrants. Economic immigration dwindled during the long recession of the $1990 \mathrm{~s}$, but 


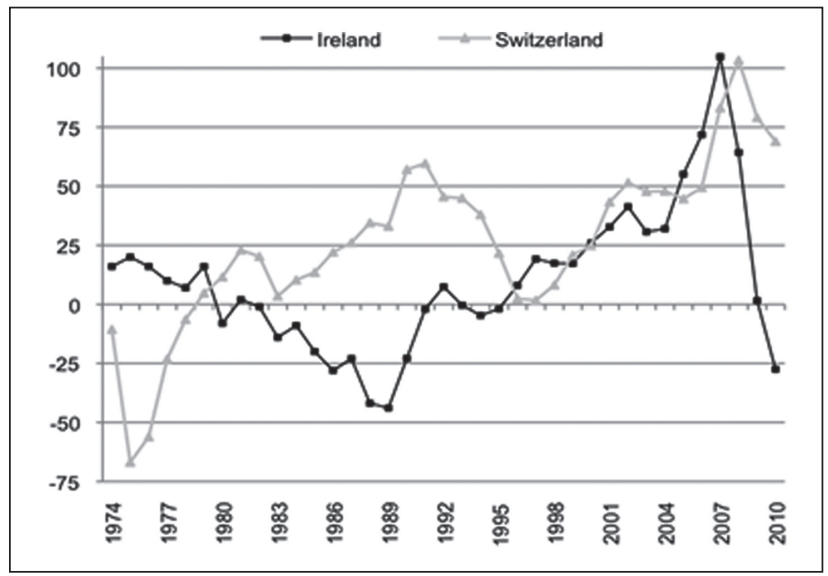

Figure I. Net migration in Ireland and Switzerland, 1974-2010 (in 1000 individuals). Source: Central Statistics Office Ireland, Swiss Federal Office of Statistics.

soared again in the 2000s as many high-skilled immigrants, mostly professionals from neighbouring EU countries, entered the Swiss labour market.

Were the evolution of educational attainment and the employment structure to go hand in hand, we would expect clear-cut occupational upgrading in Ireland and Switzerland. However, the placement of migrant labour is subject to fluctuations due to changing migration policies - and the contribution of immigrants to labour supply is inadequately captured by data on their educational attainment. Overqualification in Ireland was common during the 'Celtic Tiger' years among immigrants with higher levels of education. Many accepted unskilled and low-paid jobs in hospitality and manufacturing (OECD, 2007).

Against this, Switzerland had one of the lowest overqualification rates among immigrants within the OECD in the early 2000s (OECD, 2007: 137). This was a direct result of a radical policy turn following Switzerland's recession of the 1990s (Flückiger, 1998). Migration policy shifted from recruiting less educated immigrants for jobs in manufacturing, construction and agriculture to a legal preference for highly skilled migrants. Thus, from the 2000s onwards, highly qualified migrant labour began to outnumber low qualified in the Swiss labour market.

The institutional contexts of our country cases also differ from the US and UK in the level and trajectory of wage coordination over the last few decades. Ireland's industrial relations system has traditionally been decentralised, sharing many features of the British system. Yet while the UK deregulated collective wage bargaining in the 1980s, Ireland introduced greater state coordination. Two examples are the Irish government's move to centralised bargaining as of 1987, and the setting of a national minimum wage in 2000 (Baccaro and Simoni, 2007; McGuinness et al., 2009). Ireland's coordinated bargaining has been conducted on a voluntary basis through 'social partnerships' between government and employers. The Irish case represents an interesting comparison to the UK, given the close resemblance between employer-state systems of bargaining in place in 
both countries during the 1970s. An altered political landscape during the 1980s saw a Conservative government in the UK enforce neoliberal policies which undermined workers' unions and labour committees. Such an agenda was not pursued by either employers or centrist political parties in Ireland up until the financial crisis in 2008 (O'Sullivan and Wallace, 2011). Over the study period, the Irish labour market was therefore more strictly regulated than the UK and the US, with more powerful trade unions and more widespread collective bargaining.

Wage-setting in the Swiss labour market shares many features with Germany, the main difference being weaker trade unions and more lenient dismissal policies. Collective bargaining in Switzerland is largely coordinated across industries by powerful employer associations (Oesch, 2011). Labour market institutions and the welfare state still create higher hurdles for low-wage job creation in Switzerland than in Ireland, and substantially greater than in the US. Low-wage incidence in standard employment is consequently lower in Switzerland than in Ireland, and lower in Ireland than in the US. While nine per cent of full-time workers receive less than two-thirds of median earnings in Switzerland, the proportion is 20 per cent in Ireland, compared with 25 per cent in the US, on the basis of data from the years 2005 and 2006 (OECD Statistics, 2015).

Central to the routinisation argument is timing: affluent economies should experience polarisation only at the onset of widespread use of ICT in the workplace. Empirically, polarisation should not precede the 1990s in either country. If we instead focus on labour supply and wage-setting institutions, upgrading seems likely in the recessionary decades of the 1970s and 1980s and the sluggish growth period of the early 1990s in Ireland. Polarisation seems likely in the boom period between the mid-1990s and mid-2000s. In times of positive labour supply shocks in the form of migrant and female labour participation, it is likely that the Irish labour market created jobs at both ends of the occupational hierarchy.

The period when polarisation seems likely in Switzerland is the consumption boom of the 1980s which led to a housing bubble, during which the Swiss labour market drew in large numbers of less educated migrant workers to staff low-end jobs. For the 1970s, 1990 s and 2000s, the interaction of coordinated wage bargaining and educational expansion (including a migration regime restricted to qualified immigration in the 2000s) makes occupational upgrading a more likely outcome.

\section{Data and methods}

Our analyses are based on census data. For Ireland, we used annual cross-sections from 1971, 1981, 1991, 1996 and 2006. The Irish data were extracted from the Integrated Public Use Microdata Series (IPUMS) (Minnesota Population Center, 2013) and contained a ten per cent representative national sample. For Switzerland, the years 1970, 1980, 1990, 2000 and 2010 were selected. The Swiss data from 1970 up to 2000 were a full population census, whereas 2010 was a five per cent nationally representative sample.

Samples were restricted to all job-holders who reported being employed ${ }^{1}$ and had valid information on occupation and industrial sector. By further limiting the samples to ages 22 to $64,{ }^{2}$ we reduced the number of individuals in our analysis with marginal attachment to the labour market because they were still in education or had reached the 
legal retirement age. The data did not allow us to distinguish between full-time and parttime workers. There were no indicators on this item in the Irish data. The Swiss data only allowed for imposing a restriction of six work-hours or more per week.

For Ireland, our sample in 1971 was 80,124 and reached 170,389 in 2006. In Switzerland, the samples ranged between 2,305,578 in 1970 and 125,450 in 2010. Items with missing values reduced the number of observations in the analyses using information on nationality and educational attainment, notably in earlier decades.

To trace the evolution of job-quality quintiles over time, we adopted the analytical strategy developed by Wright and Dwyer (2003). Occupations were first distinguished as precisely as possible. Over the study period, the Irish Census coded occupations according to several country-specific schemas. ${ }^{3}$ These schemas are translated into ISCO-88 at the one-digit level in IPUMS, which provided us with nine occupational groups. In addition to occupations, we used the available information on 14 economic sectors. For our Irish sample, we thus defined an occupation based on a matrix of nine occupational groups by 14 economic sectors.

For Switzerland, occupations were defined according to ISCO-88 at the detailed fourdigit level, available for 1970-2000. For 2010, we translated ISCO-08 to ISCO-88 (Lambert and Griffiths, 2012). Since this coding scheme already incorporates relevant industry distinctions, we only used a six-sector variable to further disaggregate certain large and indiscriminate occupations, such as general managers, protective service workers, secretaries and clerks. In both countries, occupations with fewer than 30 observations were collapsed into neighbouring occupations. This left us with 89 occupations for Ireland and 177 for Switzerland.

Jobs were defined as 'good' or 'bad' based on median wages: the higher an occupation's median wage, the better the occupation. Multiple job attributes matter to workers and affect a job's quality: wages, skill requirements, promotion prospects, job security or work autonomy. While they encapsulate distinct dimensions of a job, they are closely correlated (De Bustillo et al., 2011). Our analysis uses earnings as arguably the most consequential indicator of an occupation's quality which is reliably measured and comparable.

Information on earnings was not included in the census data. The earliest wage data available to determine our country-specific job rankings began in the early $1990 \mathrm{~s}$, a period which roughly corresponded to the mid-point of our analysis. For Ireland, we pooled the years 1994-1999 from the Living in Ireland (LII) survey, the Irish component of the European Community Household Panel (ECHP) (Watson, 2004). For Switzerland, we pooled the years 1993-1998 from the Swiss Labour Force Survey (SLFS, 2013).

The median wage of each occupation was calculated over these six years by averaging, for each occupation, the hourly median earnings (expressed in constant 2010 prices). Identical sample restrictions as for the census data were used to compute occupational median wages. Two additional conditions were that individuals worked at least eight hours per week and that occupations held a minimum of 20 valid wage observations.

Each country's rank-ordered occupations were then classified into one of five quintiles, each of which comprised as close to 20 per cent of total employment in all base years. Earnings were used solely to determine the 'quality' of an occupation - not to analyse the evolution of wage inequality. 
The allocation of occupations into quintiles assumes that a country's occupational ranking by median wages remained constant between the 1970s and 2000s. We tested this assumption by plotting the rankings of occupations by wages in 1991-1993 against their wage rankings in 2009-2011 for Switzerland (the period for which we had wage data). The Spearman's correlation coefficient of the two rankings was 0.89 (see Figure A.1 in the Online Appendix) and suggested that the occupational rank-order was stable over time.

We checked the reliability of our results with a second set of analyses. Instead of wages, an occupation's quality was measured using the average education of the occupational incumbents, with the idea that workers' education proxies for an occupation's skill requirements. ${ }^{5}$ As will be shown below, our two measures of job quality led to similar conclusions in terms of occupational change.

\section{Occupational change in Ireland and Switzerland}

Figure 2 displays the pattern of employment change across the five quintiles for Ireland and Switzerland over the past four decades. The two countries share a common longterm picture of occupational upgrading. The employment share of the four lower quintiles 1 to 4 decreased, whereas employment greatly expanded in the top-end quintile 5, such as for financial managers, school teachers, and senior officials in health and social services. While the two countries differed in the extent to which the lower and middle quintiles declined, the greatest employment losses took place towards the bottom end of the occupational hierarchy. Over the span of 40 years, quintiles 1 and 2, comprised of elementary occupations as well as skilled agricultural and manufacturing jobs, fell together by 12 percentage points (p.p.) in Ireland and by 16 p.p. in Switzerland.

Occupations with the strongest decline comprised many male-dominated manual occupations in manufacturing and agriculture: farmhands, manufacturing labourers and

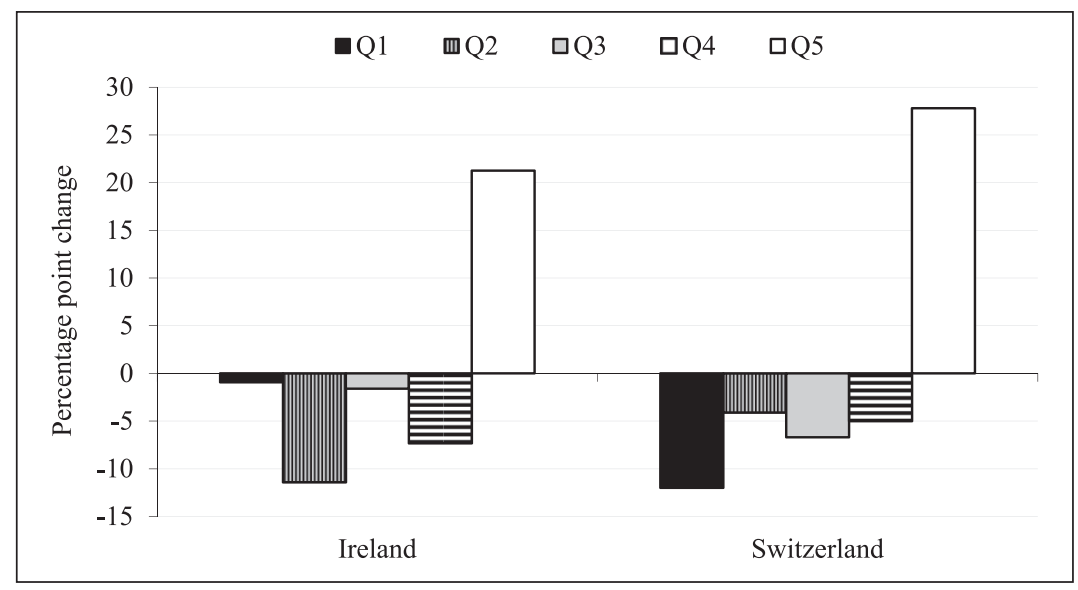

Figure 2. Occupational change across quintiles in Ireland (197I-2006) and Switzerland (1970-2010) (relative change in employment). 


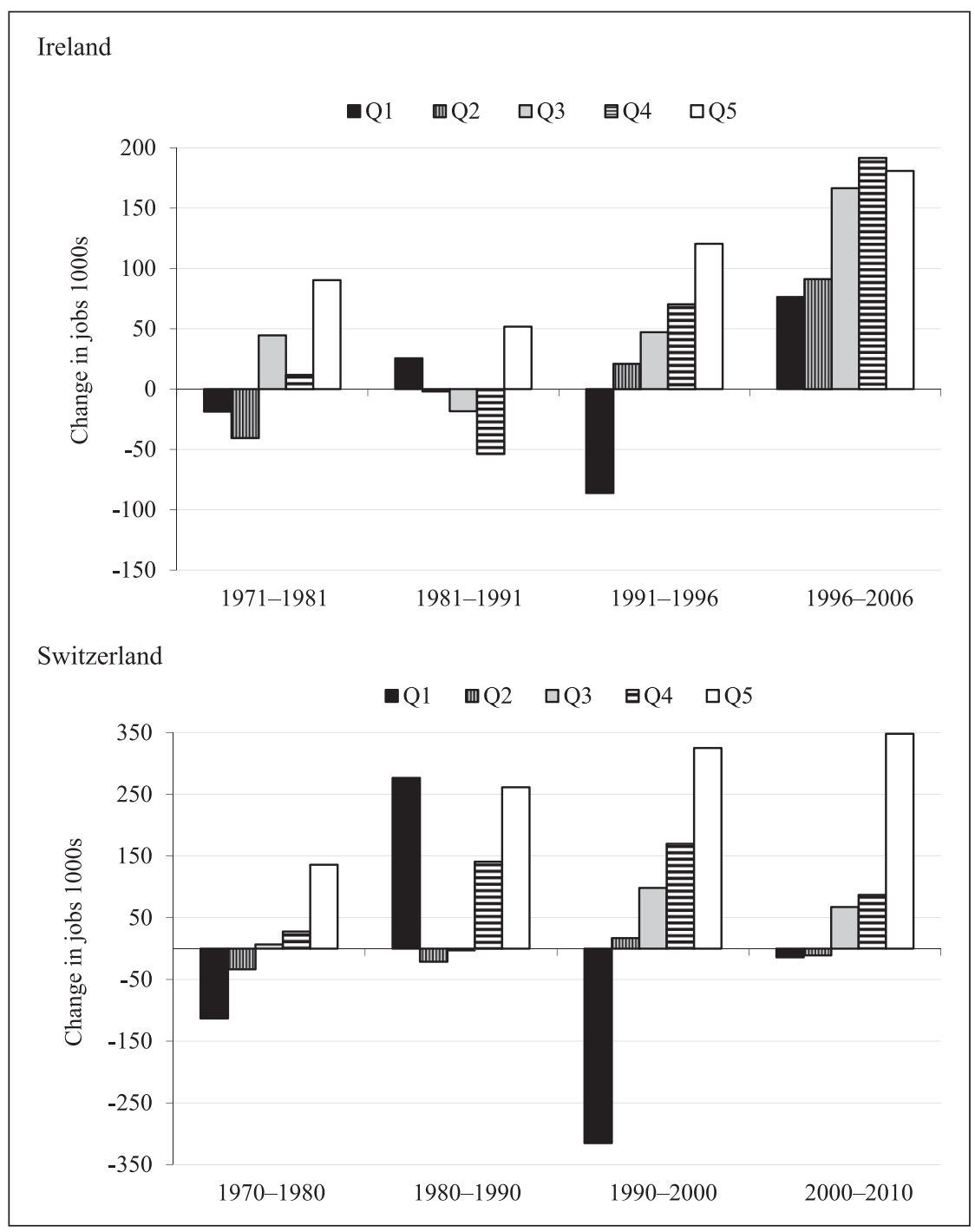

Figure 3. Occupational change across quintiles in Ireland and Switzerland by decade (absolute change in employment).

crafts workers. In Switzerland, secretaries in manufacturing also witnessed strong job decline over the last four decades. By contrast, the number of jobs grew in both countries in occupations associated with education, social welfare and business services disproportionately set in the top quintile 5 .

Crucial for the routinisation thesis is that polarisation trends appear at a time when computer technologies made a breakthrough in workplaces. We tested this expectation by analysing employment changes by decade (Figure 3). Absolute numbers in 1000 jobs 
were computed to account for differences in the business cycle and absolute growth in jobs over the last 40 years.

In the two decades preceding ICT overhaul in workplaces, the 1970s and 1980s, our results point towards both upgrading and polarisation. In the 1970s, job creation was concentrated in high-paid occupations, with a net growth in quintile 5 of 90,000 jobs in Ireland and over 100,000 jobs in Switzerland. Quintile 5 expansion constituted 80 per cent of net job growth in Switzerland and 62 per cent in Ireland.

An unequivocal polarisation of the employment structure appeared in both countries during the 1980s, with the strongest job growth in quintiles 1 and 5. Slower off the mark in its transition to a post-industrial society (Whelan and Layte, 2006), Ireland experienced a recession during much of the 1980s. With unemployment high, mass emigration followed, concentrated among the higher educated. Nevertheless, quintile 5 increased considerably, albeit by half the amount of the previous decade, spurred by growth among professionals in education and business services, particularly in finance.

Switzerland's economy was in better shape in the 1980s as construction boomed and employment expanded in quintiles 4 and 5. Growth in the labour market's top end was flanked by a massive increase in employment in quintile 1. More than a quarter of a million jobs were created in Switzerland's low-end quintile 1, where growth was greatest among manufacturing labourers and, just as in Ireland, sales assistants.

The 1990s gave way to straightforward upgrading in Ireland and Switzerland, which continued into the 2000s. The finding of clear-cut upgrading and steep losses in quintile 1 runs contrary to the evolution predicted by routinisation: the broad diffusion of computer technology did not fashion a polarised pattern of occupational change.

In Switzerland, job growth between 2000 and 2010 was heavily concentrated in quintile 5, notably among computer analysts and business professionals. The Irish occupational structure underwent a remarkable expansion of employment. Between 1996 and 2006 , over half a million jobs were created. Technological innovation played a decisive role in economic prosperity and, yet, not only did top-end occupations continue to grow, so too did mid-level occupations, particularly among clerks in finance and business services as well as education (associate-) professionals.

Overall, the rise in mid- and high-paid occupations by far outweighed growth in lower paid ones and led to upgrading - a conclusion also drawn by a more extensive analysis of the jobs boom during the Celtic Tiger years (O'Connell and Russell, 2007).

\section{Changing labour supply: Migrant, female and educated workers}

Studies on occupational change frequently use survey data to cover short time periods of 10-15 years. However, shifts in the employment structure are long-term phenomena that require historical data; otherwise, studies risk showing (transitory) business cycle effects. Likewise, a comprehensive definition of the labour force is also essential. Yet it is common in economics to exclude migrant, part-time or agricultural labour in analyses of occupational change. Goos et al. (2014) studied multiple European countries but excluded workers from several sectors (agriculture, mining, public administration and education) and occupations (senior officials, teaching professionals and associate professionals, 
agricultural workers). Dustmann et al. (2009) assessed German labour market changes while excluding the self-employed, employers, civil servants, part-time workers and women. Spitz-Oener's (2006) study of Germany excluded the self-employed, employers, immigrants and agricultural workers.

Their analyses rest on the assumption that the changing job pattern of male full-time, private-sector, non-agricultural national employees accurately reflects the changing job pattern of part-timers (majority female), civil servants, agricultural workers, migrants and the self-employed. This assumption seems a strong one. The sample restrictions appear as problematic omissions since the employment shares of these same categories have been anything but stable over the last few decades. We illustrate this point - and the influence of changing labour supply - by decomposing occupational change by four gender-nationality groups: male and female nationals, and foreign-born men and women (Figure 4). ${ }^{6}$

During Switzerland's construction boom of the late 1980s and Ireland's Celtic Tiger years, migration policies promoted the recruitment of immigrants for low-end jobs in construction, hotels and restaurants (Flückiger, 1998; OECD, 2007). Consequently, in the decade in which employment polarisation appeared in Switzerland, the 1980s, two-thirds of job expansion in the bottom quintile 1 was accounted for by growth in the number of foreign men and women. Foreign-born workers' contribution to occupational change in Ireland was evident only between 1996 and 2006. Irish employers used the influx of male migrants to bolster growth in the mid-ranking occupations, whereas female migrants were hired at both ends of the occupational structure.

The results in Switzerland show how a shift in policy can channel migrant labour. High-skilled foreign workers were actively targeted following the recession in the early 1990s, which corresponded with a drop in migrant workers' employment in quintile 1. Over both the 1990s and 2000s, immigrants helped expand occupations at the top end: migrants employed in quintile 5 saw a modest increase during the 1990s and a great increase in the 2000s. Hence, unlike in the UK (Oesch, 2013), Spain (Oesch and Rodríguez Menes, 2011) or the US (Wright and Dwyer, 2003: 309), an inflow of migrant workers into the Swiss labour market led not to polarisation post 1990 but rather to unambiguous occupational upgrading.

A concern with our analysis is that the way job quality is measured alters the form of occupational change. Notably, ranking occupations by earnings yields different results from ranking occupations by (educational) skills. As a robustness check we rank-ordered occupations on the basis of job-holders' mean education, the idea being that an incumbent's education proxies for an occupation's skill requirements. The results, occupational change by decade, are displayed in Figure A.2 in the Online Appendix.

The substantive conclusions remain the same. A skill-based measure again indicated clear-cut occupational upgrading for the 1970s and 2000s in Ireland, as well as the 1970s and 1990s for Switzerland. Periods of job polarisation switch from the 1980s to the early 1990 s before the onset of the boom in Ireland. In Switzerland, it was the 2000s that were marked by strong employment growth in quintile 5, alongside some growth in quintile 1 . This j-shaped pattern of occupational change was entirely driven by employment gains at the bottom-end among foreign men and, above all, foreign women. 


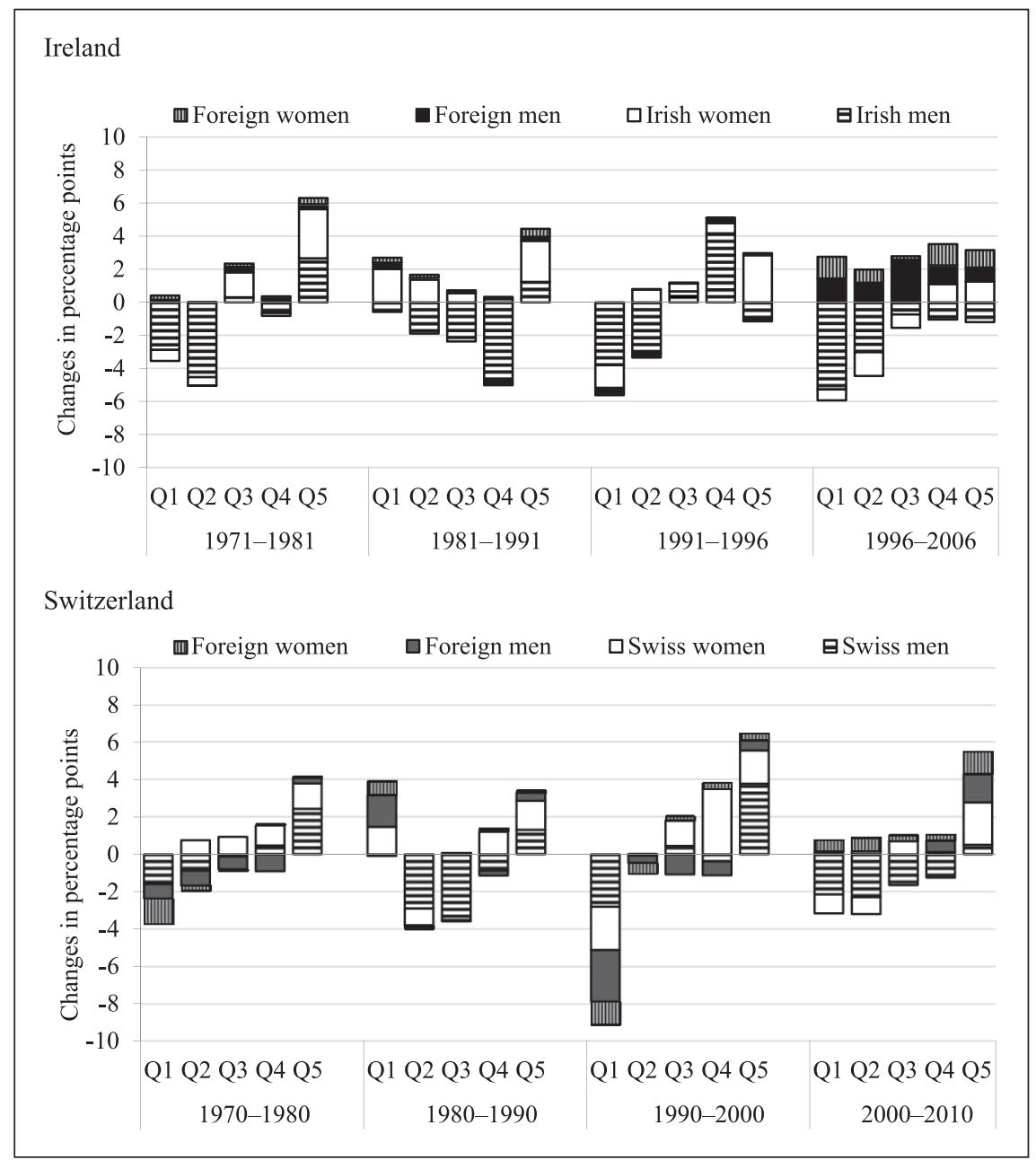

Figure 4. Occupational change in Ireland and Switzerland by gender and migrant status (relative change in employment).

The last set of analyses examines shifts in labour supply by combining gender and three educational levels: women and men with low, medium or high levels of education (see Figure A.3 in the Online Appendix). ${ }^{7}$ The most noticeable change is the labour market entry of women with intermediate and higher education levels in Ireland and Switzerland. In the 1970s, women with upper secondary education across the board growth in the occupational structure. Women's employment evolved in a U-shaped fashion in both countries during the 1980s, with gains both in the bottom quintile 1 and the top quintile 5 .

From 1990 onwards, women with medium and higher levels of education were the main architects of occupational upgrading in both countries, spurring job growth 
in quintiles 4 and 5. The impact of tertiary educated women's labour participation was particularly strong in the 2000s. Higher educated women contributed much more to employment growth in the top quintile 5 than did higher educated men in Ireland during 1996-2006 and Switzerland during 2000-2010.

While tertiary educated women and men both spurred employment expansion in topend occupations, the diminishing group of men with only mandatory schooling were responsible for the job declines in quintiles 1 to 4 in the 1970s and 1980s. In the 1990s and 2000s, it was the employment share of men with upper-secondary education that contracted in the two bottom quintiles in both countries.

An alternative way to highlight our point would be to follow previous studies (such as Dustmann et al., 2009) and restrict our analytical sample to male nationals. A finding of employment polarisation would be found on two grounds: one is a marked tendency for employment among male nationals to decrease in the middle quintiles, and the second is that the removal of women leads to much less employment expansion in the top quintiles.

\section{Discussion and conclusions}

A question arising from our analysis of two small economies is how applicable our results are to other institutional contexts. In answer, it is worth pointing to two findings and the conclusions which can be drawn from them.

First, this article has argued that shifts in labour supply are critical for occupational change. Differing educational profiles among natives are shown to underlie patterns of top-end growth and the placement of immigrant labour for bottom-end growth in Ireland and Switzerland. Low-skilled migrant labour fuelled the polarisation in the 1980s in Switzerland, which entailed a disproportionate rise in quintile 1. Similarly, during the recent Irish boom, foreign-born workers provided ample supply for bottom-end job creation, but considerable numbers also entered into mid-level occupations. Switzerland's policy turn in the 2000s towards skilled immigration restricted growth in bottom-end jobs, while leading highly educated foreign workers to contribute as much to job growth in quintile 5 as native women, and more so than native men.

Second, the analyses by decades highlight that occupational change has varied substantially over time. The variability in growth of low-end jobs is particularly important. These changes over time point to specific educational, gender and migratory regimes that work in tandem with technological progress to help or hinder low-wage, low-skill job outcomes. Importantly, the extent of low-end job creation depends on labour market institutions: wage bargaining, legal minimum wages and the welfare state expand or restrict the scope for low-wage employment. The ways in which employers are encouraged to view technology as complementary to, or as a substitute for, job tasks is vital to understanding variability in employment structures across different countries (Streeck, 1997).

Overall, our results cast doubt on an argument popular in economics that occupational change is solely determined by technology (Autor et al., 2003; Goos et al., 2014). Accounts of employment change that revolve around exogenous technological forces 
posit a clear timing effect: polarisation should set in as ICT begin to dominate the workplace in the 1990s and should continue throughout the 2000s (Autor et al., 2003). Yet the findings for Ireland and Switzerland do not fit well with routinisation as the primary driver of national employment structures. Since 1990, there was neither a hollowing out of the employment structure's middle nor disproportionate growth in its bottom-end.

In both countries, top-end job expansion was responsible for 70 per cent of total employment expansion. This was complemented by growth over the $2000 \mathrm{~s}$ in lower paid occupations in the health sector, as the number of service workers in health in Ireland and home-based personal care workers in Switzerland expanded. However, this evolution was quantitatively too small to shift the job structure towards polarisation.

Polarised employment change is confined to one of four time periods under study, the $1980 \mathrm{~s}$ - a period that precedes widespread diffusion of ICT in workplaces. Our evidence of occupational change thus counters the idea of employment polarisation as a uniform and encompassing trend across countries, and suggests that a polarised job structure can be an outcome specific to particular labour market conditions. In the two countries, the overarching shift in the employment structure over the last 40 years has been towards upgrading. In light of these findings, it is difficult to extrapolate an hourglass pattern of employment from the US and the UK to other European countries (see also FernándezMacías and Hurley, 2017), and harder still to interpret technology as the sole driver of national employment outcomes.

This article thus cautions against technological determinism. Change in contemporary job structures is shaped by specific historical conditions (Nolan and Slater, 2010). While a radical de-industrialisation of the UK in the 1980s under Thatcher, or the speculative housing boom in Spain during the early 2000s, changed the job structure, technology alone is an insufficient explanation of these shifts. Similarly, in countries where agricultural employment was still sizeable in the 1990s and 2000s (such as in Ireland or in Scandinavia), an ongoing decline in bottom-end jobs among farmhands limited the extent of growth in quintile 1, and hence occupational polarisation (Oesch, 2013: 118).

Shifts in a country's occupational structure must be understood with reference to an idiosyncratic political context that applies to key industries at a given moment in time. Consequently, any explanation of occupational change requires a multi-causal historical narrative where social agency and political strategies in job creation figure prominently (Nolan and Slater, 2010). In the case of Ireland and Switzerland, we argue that specific labour market institutions, education systems and migration policies have created the incentive structures for employers to apply technology in certain ways, and to create or destroy certain jobs. As such, it should come as no surprise that the same evolution of technology as in the UK and US does not result in identical employment structures elsewhere.

\section{Acknowledgements}

Data used in this article were made available by the Swiss Federal Statistics Office, the Central Statistics Office Ireland, the Irish Social Science Data Archive, and the Minnesota Population Center, none of whom bear any responsibility for the analysis or interpretation of the data reported here. The authors would also like to thank Fabrizio Bernardi, Marlis Buchmann, Felix Bühlmann, Francesco Laganà, Rafael Lalive and the three anonymous reviewers for their insightful comments and suggestions. 


\section{Funding}

The authors disclosed receipt of the following financial support for the research, authorship, and/ or publication of this article: this research benefitted from the financial support of the Swiss National Science Foundation, as part of NCCR LIVES at the University of Lausanne.

\section{Notes}

1. The exceptions were unpaid family workers and apprentices in Switzerland and, unfortunately, the Irish data did not allow for an exclusion of unemployed persons between 1971 and 1991. The 2002 Census coding used an International Labour Organization (ILO) definition of the active employed population and this was checked with our sample; numbers were relatively similar.

2. The Irish Census samples were restricted by age groups, and consequently the oldest individuals for these analyses were aged 62. In Switzerland, we imposed an age limit of 63 for our sample of women.

3. These occupational classifications share similarities with the UK SOC-68 and SOC-90. For this reason, we make use of the generated one-digit ISCO- 88 variable that spans all decades. While this is harmonised to some extent across the years, a major coding break occurred in 1991, such that the ISCO-88 classification stemmed from the same underlying classification schema between 1971 and 1991, and another schema between 1996 and 2006.

4. Data from the LII were accessed via the Irish Social Science Data Archive - www.ucd.ie/ issda. Data from the SLFS were accessed via the Swiss Federal Statistics Office. Any interpretation of the data or errors reported here are our own.

5. This way of measuring job quality can be problematic. However, we followed past research and aggregated education into three levels: lower secondary schooling or less; upper secondary - general or vocational - education; and tertiary education. Occupations are then rankordered by mean educational attainment of the workers. Quintile 1 comprises the 20 per cent of employment set in occupations with the lowest average educational level; quintile 5 comprises the 20 per cent of employment set in occupations with the highest average educational level.

6. In Figure 4, 'foreign' status is not directly comparable between the two countries. For Ireland, 'foreign' refers to foreign-born workers whereas for Switzerland 'foreign' refers to men and women who report having foreign nationality. While Ireland has a lengthy history of emigration and return migration of Irish nationals, it only began receiving large numbers of foreign immigrants during the 1990s. The Census only started to differentiate between foreign-born and nationality in 2002. For 2006, our sample of foreign-born contains five per cent who are born abroad but are Irish nationals.

7. Owing to how education was originally recorded between 1971 and 1991, education groups in Ireland for this time period refer to (I) primary or less; (II) some secondary or vocational schooling; and (III) any tertiary. In Switzerland, and Ireland for 1991-2006, these are (I) those with less than upper secondary education; (II) upper secondary and post-secondary schooling; and (III) tertiary-level degree.

\section{References}

Acemoglu D (2003) Cross-country inequality trends. The Economic Journal 113(485): 121-149.

Anderson P (2009) Intermediate occupations and the conceptual and empirical limitations of the hourglass economy thesis. Work, Employment and Society 23(1): 169-180.

Autor DH, Katz LF and Kearney MS (2008) Trends in U.S. wage inequality: Revisiting the revisionists. Review of Economics and Statistics 90(2): 300-323. 
Autor DH, Levy F and Murnane RJ (2003) The skill content of recent technological change: An empirical exploration. Quarterly Journal of Economics 118(4): 1279-1334.

Baccaro L and Simoni M (2007) Centralized wage bargaining and the 'Celtic Tiger' phenomenon. Industrial Relations 46(3): 426-455.

Barrett A, FitzGerald J and Nolan B (2002) Earnings inequality, returns to education and immigration into Ireland. Labour Economics 9(5): 665-680.

Becker R and Zangger C (2013) Die Bildungsexpansion in der Schweiz und ihre Folgen. Kölner Zeitschrift für Soziologie und Sozialpsychologie 65(3): 423-449.

De Bustillo RM, Fernández-Macías E, Antón J, et al. (2011) E pluribus unum? A critical review of job quality indicators. Socio-Economic Review 9(3): 447-475.

DiPrete T and McManus PA (1996) Institutions, technical change, and diverging life chances: Earnings mobility in the United States and Germany. American Journal of Sociology 102(1): 34-79.

Dustmann C, Ludsteck J and Schönberg U (2009) Revisiting the German wage structure. Quarterly Journal of Economics 124(2): 843-881.

Dwyer R (2013) The care economy? Gender, economic restructuring, and job polarization in the U.S. labour market. American Sociological Review 78(3): 390-416.

Eurofound (2015) Upgrading or Polarisation? Long-term and Global Shifts in the Employment Structure: European Jobs Monitor 2015. Dublin: European Foundation for the Improvement of Living and Working Conditions.

Fernández-Macías E (2012) Job polarization in Europe? Changes in the employment structure and job quality, 1995-2007. Work and Occupations 39(2): 157-182.

Fernández-Macías E and Hurley J (2017) Routine-biased technical change and job polarization in Europe. Socio-Economic Review 15(3): 563-585.

Flückiger Y (1998) The labour market in Switzerland: The end of a special case? International Journal of Manpower 19(6): 369-395.

Gautié J and Schmitt J (eds) (2010) Low Wage Work in the Wealthy World. New York: Russell Sage Foundation.

Goldin C and Katz LF (2007) Long-run changes in the wage structure: Narrowing, widening, polarizing. Brookings Papers on Economic Activity 2: 135-167.

Goos M and Manning A (2007) Lousy and lovely jobs: The rising polarization of work in Britain. The Review of Economics and Statistics 89(1): 118-133.

Goos M, Manning A and Salomons A (2014) Explaining job polarization: Routine-biased technological change and offshoring. American Economic Review 104(8): 2509-2526.

Grimshaw D, Bosch G and Rubery J (2013) Minimum wages and collective bargaining: What types of pay bargaining can foster positive pay equity outcomes? British Journal of Industrial Relations 52(3): 470-498.

Holmes C and Mayhew K (2012) The Changing Shape of the UK Job Market and its Implications for the Bottom Half of Earners. London: Resolution Foundation.

Honohan P and Walsh B (2002) Catching up with the leaders: The Irish hare. Brookings Papers on Economic Activity 1: 1-77.

Kalleberg A (2012) Job quality and precarious work: Clarifications, controversies, and challenges. Work and Occupations 39(4): 427-448.

Keane C, Russell H and Smyth E (2016) Female participation increases and gender segregation. Working Paper, The Economic and Social Research Institute (ESRI), Dublin.

Lambert P and Griffiths D (2012) Dimensions and boundaries: comparative analysis of occupational structures using social network and social interaction distance analysis. Sociological Research Online 17(2): 1-23. For further details see: http://www.camsis.stir.ac.uk/ (accessed: 30 September 2017). 
Lewis E (2006) Immigration, Skill Mix, and the Choice of Technique. Philadelphia, PA: Federal Reserve Bank of Philadelphia, 1-43.

McCollum D and Findlay A (2015) 'Flexible' workers for 'flexible' jobs? The labour market function of A8 migrant labour in the UK. Work, Employment and Society 29(3): 427-443.

McGuinness S, McGinnity F and O'Connell PJ (2009) Changing returns to education during a boom? The case of Ireland. Labour 23(1): 197-221.

Manning A (2004) We can work it out: the impact of technological change on the demand for lowskill workers. Scottish Journal of Political Economy 51(5): 581-608.

Méhaut P, Berg P, Grimshaw D, et al. (2010) Cleaning and nursing in hospitals: Institutional variety and the reshaping of low-wage jobs. In: Gautié J and Schmitt J (eds) Low Wage Work in the Wealthy World. New York: Russell Sage Foundation, 319-366.

Minnesota Population Center (2013) Integrated Public Use Microdata Series International. Minneapolis, MN: University of Minnesota; Cork: Central Statistics Office.

Nolan P and Slater G (2010) Visions of the future, the legacy of the past: demystifying the weightless economy. Labor History 51(1): 7-27.

O'Connell P and Russell H (2007) Employment and the quality of work. In: Fahey T, Russell H and Whelan C (eds) Best of Times? The Social Impact of the Celtic Tiger. Dublin: Institute of Public Administration, 43-66.

OECD (2007) International Migration Outlook. Paris: OECD.

OECD (2015) OECD Stat.Extract. Available at: http://stats.oecd.org (accessed 11 February 2015).

OECD (2017) International Migration Database. OECD.Stat. Available at: https://stats.oecd.org/ Index.aspx?DataSetCode=MIG (accessed 30 September 2017).

Oesch D (2011) Swiss trade unions and industrial relations after 1990: A history of decline and renewal. In: Trampusch C and Mach A (eds) Switzerland in Europe. Continuity and Change in the Swiss Political Economy. London: Routledge, 82-102.

Oesch D (2013) Occupational Change in Europe: How Technology and Education Transform the Job Structure. Oxford: Oxford University Press.

Oesch D and Rodríguez Menes J (2011) Upgrading or polarization? Occupational change in Britain, Germany, Spain and Switzerland, 1990-2008. Socio-Economic Review 9(3): 503-532.

O'Sullivan M and Wallace J (2011) Minimum labour standards in a social partnership system: The persistence of the Irish variant of Wages Councils. Industrial Relations Journal 42(1): 18-35.

Rodriguez N (2004) 'Workers wanted': Employer recruitment of immigrant labour. Work and Occupations 31(4): 453-473.

Spitz-Oener A (2006) Technical change, job tasks, and rising educational demands: Looking outside the wage structure. Journal of Labour Economics 24(2): 235-270.

Streeck W (1997) Beneficial constraints: On the economic limits of rational voluntarism. In: Hollingsworth JR and Boyer R (eds) Contemporary Capitalism: The Embeddedness of Institutions. Cambridge: Cambridge University Press, 197-219.

Swiss Labour Force Survey (SLFS) (2013) Neuchâtel: Federal Statistical Office. For further details see: https://www.bfs.admin.ch/bfs/en/home/statistics/ (accessed 11 February 2015).

Turner T and McMahon J (2011) Women's occupational trends in the Irish economy: Moving towards high-skilled occupations or evidence of deskilling? Gender, Work and Organization 18(1): 222-240.

Watson D (2004) Living in Ireland Survey: Technical report and codebook for data users. Working Paper no. 163. Dublin: The Economic and Social Research Institute (ESRI).

Whelan CT and Layte R (2006) Economic boom and social mobility: The Irish experience. Research in Social Stratification and Mobility 24(2): 193-208.

Wright EO and Dwyer RE (2003) The patterns of job expansions in the USA: A comparison of the 1960s and 1990s. Socio-Economic Review 1(3): 289-325. 
Emily C Murphy is a researcher at the Centre on Skills, Knowledge and Organisational Performance (SKOPE) at the Department of Education, University of Oxford. She is currently working on an international project examining the institutional and individual determinants of young people not participating in education, employment or training (NEET). Her research focuses on occupations, inequality, and skill development in education and the labour market.

Daniel Oesch is Professor at the Life Course and Inequality Research Centre (LINES) at the University of Lausanne. His research focuses on social stratification and inequality, unemployment and labour market policy. He has published widely in the field of economic sociology and political economy, and is the author of two books: Occupational Change in Europe. How Technology \& Education Transform the Job Structure (OUP, 2013) and Redrawing the Class Map (Palgrave MacMillan, 2006).

Date submitted December 2016

Date accepted September 2017 